DOI: $10.28934 /$ jwee19.12.pp17-35

JEL: M30, M31, L26, L67

ORIGINAL SCIENTIFIC PAPER

\title{
Fashion Product Development Process with Reference to Women's Participation
}

\author{
Milica Slijepčević ${ }^{1}$ \\ Karolina Perčić ${ }^{2}$ \\ Metropolitan University Belgrade, Faculty of Management, Belgrade, Serbia
}

\section{A B S T R A C T}

The process of the development of new fashion clothing requires all actors in the process to invest tremendous effort in order for the right model to reach its customer at the right time and in the right place. Although the textile and leather processing industry in Serbia employs large number of people, little attention has been paid to fashion marketing, thus it is the subject of this paper as regards the process of the development of fashion products with reference to participation of women in this process, with the aim of presenting characteristics and specificities of the said, along with the results of the secondary research in relation to the subject mentioned.

KEY WORDS fashion product, fashion, fashion marketing, fashion diffusion, women, bloggers

\footnotetext{
${ }^{1}$ Address: Tadeuša Košćuška 63, Belgrade, Serbia, milica.slijepcevic@metropolitan.ac.rs, tel. 064/8345042

${ }^{2}$ Address: Tadeuša Košćuška 63, Belgrade, Serbia, karolina.percic@metropolitan.ac.rs, tel. 063/1074403
} 


\section{Introduction}

More than ever, the fashion industry is focused on a modern human being and its clothing needs which evolved into the need to send a message of personality through clothing and dressing style (a segment of nonverbal communication). Dressing up has become part of the modern human being's intimacy, thus the task of fashion clothing manufacturers is very complex - it requires knowledge, time, monitoring, analysis, proactivity, passion, dedication and a number of other elements that must be represented to the right extent in order to satisfy the needs and wishes of consumers.

The process of designing fashion products includes two key processes one is product adjustment, the other one is creation, and the most common is combination of these two. The process of the development of new fashion clothing requires tremendous effort of all actors in the process - from designers, manufacturers, retailers, to marketing managers - in order for the right model to reach its customer at the right time and in the right place.

The fashion market is extremely flexible and variable - seasonal collections are changed at least twice a year, and inter-season collections are often launched. As an exceptionally dynamic area, fashion is globally characterized by constant, exciting changes in the domain of creativity. However, creativity in the domain of fashion industry is not sufficient in itself and requires a number of other skills to support these new ideas and creations in order for them to survive, gain consumer audience and ensure their planned survival on the market. The constant risk of failure faced by manufacturers can be reduced and made less certain, through high-quality and well designed marketing activities that will establish continuous communication with market and with consumers. Fashion marketing enables making clear distinction between a model which ends up in a storehouse and a model which is desirable, which customers are looking for, which is purchased and worn.

In order for a fashion product to be created and to survive on the market, it requires market research, tailoring of a system of products and services offer, establishing of contacts and communication with customers on a long-term basis and a range of other activities that contribute to gaining and maintaining a stable market position.

The textile, clothing, leather and footwear industry represents significant production branches in the Serbian economy; it is import-dependent, export-oriented and labor intensive - especially the textile industry. Accord- 
ing to the Statistical Office of the Republic of Serbia - SORS (2018), textile production in 2018 employed about 11,829 workers, clothing production employed about 35,744 workers and production of leather and leather products about 13,728 workers. Compared with 2017, there is almost 7\% increase in the number of employees in these areas of production in Serbia, especially in comparison with previous years. According to the latest SORS records on the number of business entities, in 2016 there were 437 business entities engaged in the production of textiles, 957 business entities in the production of clothing and 289 business entities manufactured leather and leather products. Textile and leather processing industry is not a significant industrial branch in Serbia due to a number of companies and workers employed therein (it has the capacity to employ even more), but also due to significant export share: over \$ 1.3 million in 2017, i.e. 8\% of total exports of the Serbian manufacturing industry. As regards total exports of textile industry products (textiles and textile products) in the period 2015-2017, the reported increase in the value of exported goods stood at about $20 \%$. On the other hand, the value of textile industry imported products increased by about $20 \%$ in the reported period.

Despite the fact that Serbian fashion industry employs large number of people, insufficient attention has been paid to fashion marketing which transforms clothing into a lifestyle, and precisely for that reason it is the subject of research in this paper in terms of the process of creating fashion products with reference to women's participation in that process and with the aim of presenting the characteristics and specificities of the said, along with the results of secondary research regarding the mentioned subject.

\section{Creating Fashion}

Fashion, as part of the culture, sets trends and affects the demand, shape (design) of products and sales in the textile and clothing industry (Grilec Kaurić, 2009). In a wider sense, fashion is a sociological and cultural phenomenon which greatly influences product sales. In its narrow sense, it is a way of dressing, personal expression and a medium of communication between people (Drvar, 1997). Through development of industry and marketing, fashion enters all classes of society, constantly accelerating the rhythm of fashion changes (Odak, 2003) and representing a social example of perpetuum mobile - a fashion mechanism that, once put into circulation, 
no longer stops but continues forever and inevitably associates (Gronow, 2000).

There are different theories and experiences when it comes to research of fashion creation. One of the main theories is the one entitled "trickle down" or fashion diffusion, and the other one is "trickle up" (Chowdhary, 2015, according to: Fallers, 1954; Field, 1970). According to the "trickle down" theory, fashion moves from upper, financially more solvent classes of society, to the lower ones. Due to the constant tendency of lower economic and social groups to belong to upper groups and classes, fashion will be infiltrated and will not always fully reflect the individual's belonging to a particular group. The system that makes this possible is functioning in a way that journalists are invited to fashion shows for the sake of designers' publicity. Certain image which is presented there is further processed by them according to their vision, impressions and editorial policy, as well as according to the media, and they present the most suitable models that are sent out for the consumers public opinion - first to those who accept it rapidly, and then to those who are slower and more rigid in accepting new fashion requirements.

An example of the functioning of "trickle down" theory dates back to the end of the twentieth century: Vivienne Westwood was a creator of a pretty bold fashion idea to wear the brassiere as top outerwear over the dress. In its original form, this fashion innovation was not widely accepted. However, the fashion designer Jean Paul Gaultier took this concept over, modified it and designed dresses with shaped top, for which the pop star Madonna showed great affection. The idea, modified in such a way, finally penetrated lower to the ready-to-wear in a much conservative form, although the basic shape and design of the cone bra dress remained (Bohdanowicz \& Ciamp, 1994).

There is also a process of accepting the fashion that runs in the opposite direction - the abovementioned "trickle up" theory, or the street fashion accepted by fashion designers. It is known that fashion designers from the world's leading fashion centers often find inspiration in clubs and in the streets. One of the epochal examples proving this theory, included in the Victoria and Albert Museum collection, is Zandra Rhodes punk dress from the 1970s. Punk fashion, created in the streets, often meant that ripped clothes were reattached with chains and safety pins. According to some interpretations, this anti-fashion was made for a small amount of money since the clothes were usually bought on sale and in second-hand stores. Zandra 
Rhodes created also her own version of a little black dress using silk, tailor waste with worked edges, fine chains and safety pins with diamonds, which was launched for sale at a price of \$2,500 (Bohdanawicz \& Ciamp, 1994). In this way, the so-called street fashion became desirable in upper class as well. This British fashion designer was one of the pioneers of the new fashion wave of British designers who placed London at the forefront of the international fashion scene. Also known as a "punk princess" with her dramatic creations, she created a recognizable identity in the international world of fashion. Her creations, among others, were worn by Princess Diana, Elizabeth Taylor, Freddie Mercury and Sarah Jessica Parker in the "Sex and the City" series.

\section{Creative Process in Fashion Creation}

The process of creating a new collection is influenced by a number of factors. The process itself is conducted by a smaller or larger team of designers, while large fashion houses often engage external associates, individuals or agencies/studios, and the team is managed by a design manager. Besides the designers, marketers are also involved in the creative process of fashion product development. Fashion marketing implies the connection of fashion design and marketing, including development, promotion, sales and price aspects in the fashion industry (Grilec Kaurić, 2009). The designer is tasked with designing the product while respecting the elements of fashion and other technical and market features of the product, thus creating the conditions for marketing to perform its part of the task (Drvar, 1997).

Analysis of the market and market trends is somewhere the starting point, although in companies many of these processes take place in parallel. Acquiring the right information about market size, its ability to receive certain amount of fashion garments and other fashion items is crucial for giving guidelines and plans to the teams in charge of creating and producing fashionable clothing. In addition, data on sales, trends and other factors that may potentially influence consumer decisions (Animal Rights Movement, Green Movement) are important elements of quality analysis. Based on the analyzed elements, the market is selected and an approximate price is contracted.

The next step is to create a fashion collection. It is important to point out that the entire team of designers, as well as every member individually, should, as a rule, know what is happening in fashion centers and what the world's leading designers create. Ideally, fashion companies would allocate 
funds for their designers' visits to these fashion centers. Moreover, it is also important to visit fair events where textiles, fabrics, leather, etc. are exposed. It is necessary to continuously monitor the complete textile and leather industries. Designers with better and direct insight into fashion events have significant advantages over those who are not able to follow them.

The role of fashion forecasting agencies is important in the process of designing a fashion collection. Their services can be very expensive, but are cost-effective. Fashion houses that can seize an opportunity use their services which, as proved in practice, are ultimately worthwhile in many segments, especially when creators are not able to visit fashion shows at the world's leading fashion centers. They often issue instructions for the next season in which they present fabrics, interpretation of patterns, colors, types of weaving, and fashion houses engage them to present their forecasts.

Fashion magazines are another very important source of information. They often publish useful information regarding fashion industry and trends, and present certain creations, top selling items, etc. Other magazines, not directly dealing with fashion, can also have great influence. In the world of the Internet, everything is much more available today than 2-3 decades ago. In the last 10 years, the emergence of social networks has made real revolution in the presentation of fashion events, fashion houses, special events, etc.

The relationship between the media and designers refers to mutual influence. The media has significant impact on designers as well. By presenting sports and music stars, they can encourage designers to integrate in their designs the elements from completely different activities that enrich said designs. Creativity and inventiveness of the designers does not only rest with new ideas, but also with the incredible combinations that have already been seen. The creative process, from the moment of sketching the assortment to its launching in retail, is endless. If in the process of tailoring and sewing it is found that certain material or cut is not adequate, the model is returned to the designer for refinement. Perfection of a model in its first version is almost impossible. Finally, the collection sample (sealed sample) is sent to the quality control service in order to control the standard of serial production. The product is then ready to be purchased, and mass production can begin. 
Figure 1: Calendar of fashion activities in the process of creating a fashion collection and its placement on the market, as well as withdrawals from the market and supplies removal

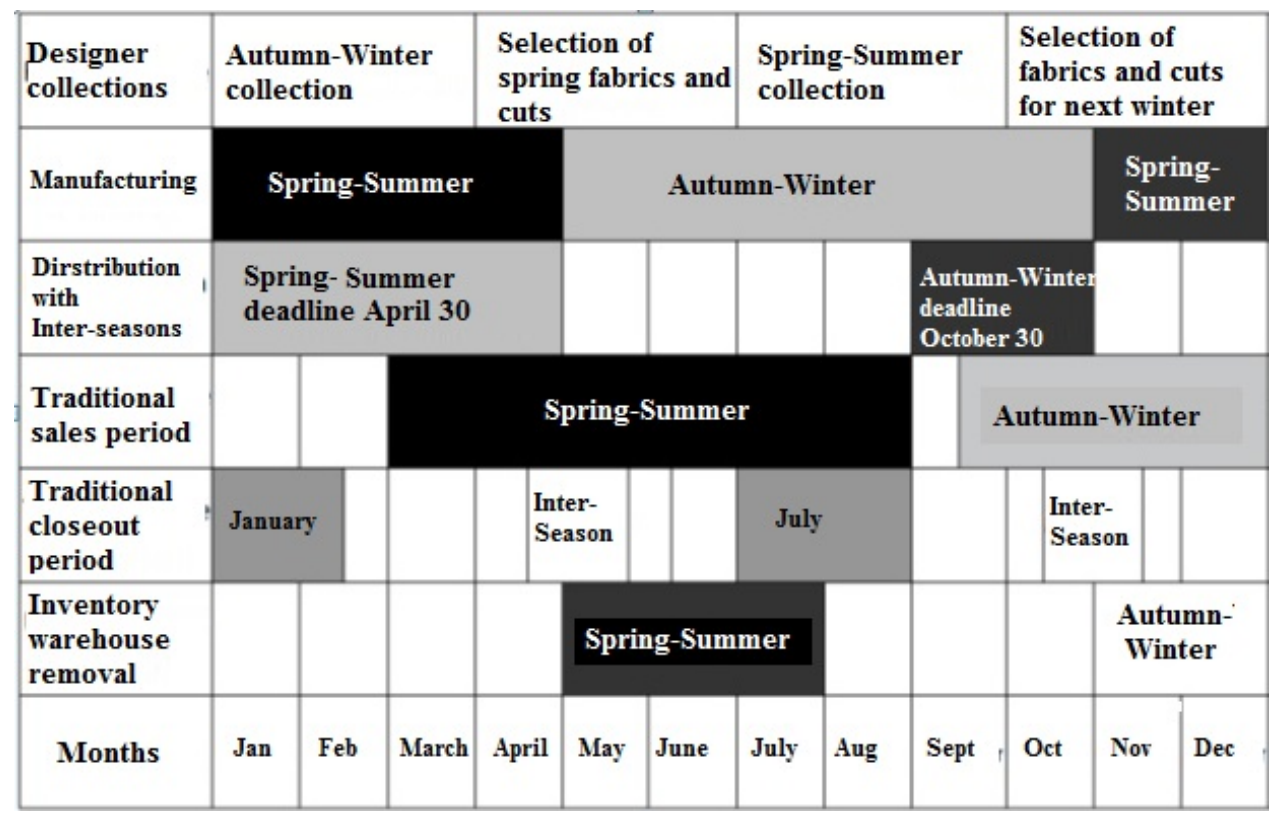

Source: Bohdanowicz \& Clamp, 1994.

\section{The Process of Fashion Diffusion, Creation of Identity and Fashion Product Image}

The process of the creation of fashion innovations was presented in the previous part of the paper and the authors will further present the process that consequently follows - diffusion of fashion innovations. These two processes jointly constitute an innovation process which is traditionally interpreted as a social process or a social change (Rogers, 1983). Understanding of the diffusion model allows understanding of the consumption of new products (Rogers, 1976).

Acceptance of fashion creation by the upper social class is extremely important because broad masses of the population identify with them and accept their dressing style. It is known that fashion shows are visited by famous actors, singers, politicians, rich businessmen, nobles, i.e. the cream of the world's society. 
In order for a particular dressing style to become fashionable, it must be widely accepted. We know of many dressing styles in our surroundings, but only some of them have become fashionable. The fact that great number of institutions have been established worldwide to study fashion as a phenomenon of global dimensions, its aspects and complex impact on all spheres of life, speaks in favor of fashion as an important segment of our lives.

One of the most renowned institutions is the "Delfo" Fashion Forecast Institute from Milan (Slijepčević, 2016). This Institute performs forecasts based on the analysis of styles (a group of designers collects information on the types of materials, fabrics, cuts, colors and styles in general), then sociological and psychological analysis of trends and fashion connection to these phenomena (to predict the trends that will evolve best). Its third area of research is film, music, painting (the underlying essence can often be discovered in these very areas).

The fashion can be divided into the three following classes: high fashion or couture - a set of styles and designs created by leading fashion authorities for small circles of upper class, current fashion or ready-to-wear current style which is widely accepted, and popular fashion or high street fashion - which is accepted by the broadest masses of the people (Gašović, 1998).

Each of these groups is intentionally targeted by designers and manufacturers through specific marketing methods used for communication with customers, but since they often intertwine in practice it is not uncommon for the greatest names of the fashion scene, specialized in couture, to address the consumers of high street fashion when designing their collections. Conversely, as strikingly evident from the previous examples, high street fashion often becomes the status symbol of the upper class consumers. No matter how carefully and thoroughly certain collections are created and fashion trends conceived, certain clothing items are sometimes spontaneously accepted to the surprise of designers and marketing experts. Fashion is definitely cumbersome and unpredictable. However, the task of fashion marketing is to minimize the surprises, and when they happen to put them as efficiently as possible in the service of their own products.

As the product label is often more important than its quality and design, and has stronger influence on the consumers decision to buy products, marketing experts pay special attention to fostering product identity and image as this further leads to the development of product brand and customer loyalty. 
From the branding point of view, an example of the fashion brand Zara is very specific and interesting in many ways. Founded by Amancio Ortega, one of the richest people in the world, this is currently the largest fashion company with a retail chain of several thousand stores worldwide. Zara is known as the initiator of instant fashion, and its business concept is based on mass production of clothes that will reach the customer as soon as possible, at the lowest price possible, and will be replaced with a new model in the shortest time possible. Zara promoted the dynamic rhythm of changing trends by launching tens of thousands of new models annually and nearly a billion clothing items, while setting up standards still unattainable for competition. The marketing philosophy of this fashion giant is that consumers are their associates in creating fashion trends that are further shaped by designers; it does not rely on famous designers and does not use classical types of advertisements, but invest in equipment of sales facilities at elite locations. Many couture producers, as well as editors of fashion magazines, are very critical of this concept. They reproach Zara for plagiarism, aggressiveness and, most of all, for uncritical use of natural resources that can have big long-term consequences.

\section{Life Cycle of a Fashion Product - Fashion, Style, Hit}

Life cycle of a fashion product is slightly different from life cycle of an ordinary product. Fashion marketing experts are primarily tasked with discovering the product and style which have the potential to reappear on the market. Fashion cycle of a fashion product is often conditioned by many impacts, such as weather, demographic and fashion trends and movement of items from the mass market to the exclusive market and vice versa. In any case, the scheme of a fashion product life cycle is beneficial primarily to the retail, because in this way there is a clear insight into the extent to which a particular product is interesting and the time for which it should be offered to consumers (Bohdanowicz \& Clamp, 1994).

The time since the introduction of a product on the market to its withdrawal from the product mix is called life cycle of a product. It is a concept that defines sales, profits, consumers, competition and marketing activities related to the product, from its emergence to its disappearance from the market. It was developed by Theodore Levitt in 1965. Life cycle of a product is one of the most controversial theoretical concepts in marketing, but has strong support in practice. 
Regardless of the longevity of life cycle, each product goes through four stages: the stage of product emergence and introduction to the market, the stage of growth and development, the stage of maturity, stability and saturation and the stage of decline and age (Kotler \& Keller, 2006).

Typical business conditions exist at each stage of life cycle. Each of these stages offers different challenges and, consequently, each stage requires different management of a product life cycle (Milosavljević, 2001).

By observing and studying product life cycle, marketing experts have noticed that certain fashion items, or clothing items, reappear several times. Above all, fashion marketing experts are tasked with discovering the product and style that have the potential to reappear on the market. Some clothing items that are in line with the fashion trend (hit, fad) are widely accepted by consumers at the initial stage already, but then there is a rapid decline in popularity and elimination from the market. The particularity of the process of clothing production, with a large number of new products for each coming season, enables the designers and manufacturers to get rapidly involved in production of "hit" clothing items.

Although the modern era in fashion terms is characterized by a mix of various clothing combinations that create the illusion that what was once known as fashion style is vanishing now, the saying of famous Yves Saint Laurent - "Fashion pales, style is eternal", is confirmed by the research presented on the charts (Figure 2), according to which fashion style lasts longer than fashion itself. Despite their meteoric success, the fashion hits disappear in the same manner, and product designers who passed the test of some verified styles can count on a long-term sales perspective.

Figure 2: Life cycle of style, fashion and hit (or fad)
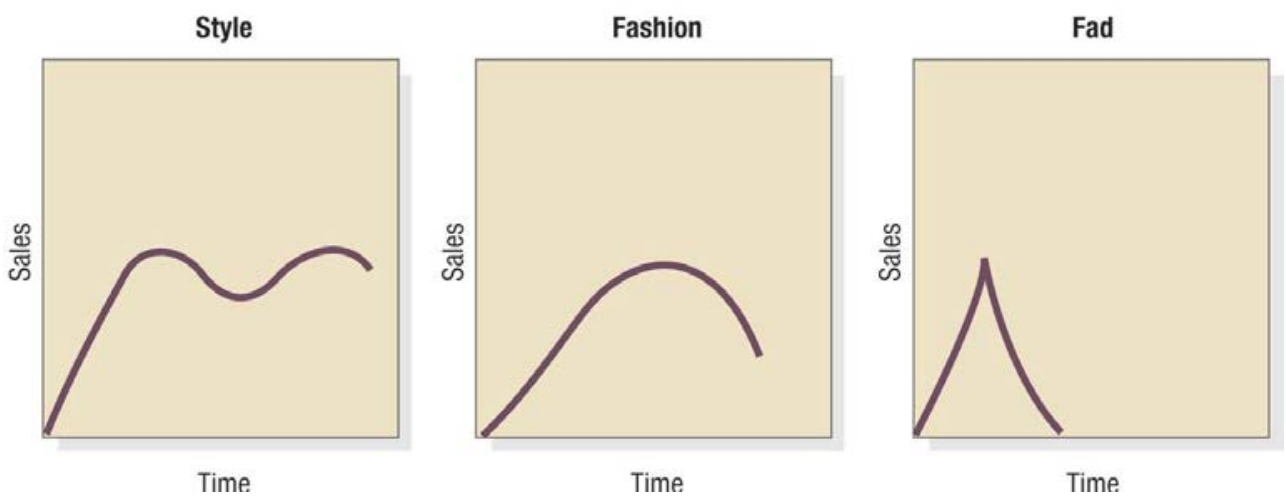

Source: Kotler, Armstrong, Saunders \& Wong, 1999. 
Example: "Bum bag" (a small bag carried around the waist) appeared as a cyclist prop, and since cycling became fashion it was followed by the market of adequate equipment and clothes. Until 1981, this bag was worn not only by cyclists, but also by nightclub visitors who carried it as a fashion detail made of a wide variety of fabrics, in a wide range of colors, from cotton tartan to gold plated PVC film. In the spring of 1990 its popularity in street fashion started to decline. At this stage, it appeared as a detail in a high fashion collection. "Chanel" presented a kilt version, "Hermes" and "Gucci" presented brightly colored bags with important messages imprinted. Copies of these couture versions were soon widely sold and available from serial production. They gained greater fame because they were counterfeit the same bag was born again. Wise merchants have come with the idea to make it an ideal accessory for people on holiday, so the same bag was produced as a travel accessory and, as such, was particularly popular among fifty-year-olds (Bohdanowicz \& Ciamp, 1994) and now, it "lives" again in 2018 and 2019.

\section{Fashion Product Pricing}

No matter how brilliant the manufactured item is, the question of its survival solely depends on the answer to the following question: Who will buy it? Apart from answering this question, the price is one of the key and crucial factors in making purchase decisions. Therefore, pricing as an element of the marketing mix of a fashion product is of great importance. Increasing competition on the international fashion market urges marketing experts to focus more on pricing issues.

"In its most basic form, pricing has little to do with what consumers are willing to pay" (Gašović, 1998). Regarding the costs, pricing takes into account the following: gross margin, i.e. the total profit expressed as a percentage of the selling price of an item, the average gross margin derived from gross margin of all items (not all items are sold equally), fixed costs mainly the last year's fixed costs increased by the \% of inflation (rent, tax, insurance, debts, wages), variable costs - vary depending on the volume of production (if the production increases, the administration, number of employees and raw materials increase as well), semi-variable costs - when the same number of employees work longer due to an increased volume of production, their wage is increased accordingly but no new workers are engaged because this is a seasonal increase in the volume of work (Slijepčević, 
2016). These are only key cost categories. However, when forming the price in the fashion industry, account should be taken of a series of other elements such as employee training, costs of introducing new technology, operating costs for standard and non-standard operations, direct costs (material and labor), indirect general costs, etc. In any case, it is necessary to keep records of costs for each detail, which begins at the design department. Only meticulous cost management can significantly facilitate the process of item price determination, and can therefore yield the expected profit.

In forming the final price in large companies, knowledge of the cost structure and cost management is of paramount importance. The account should also be taken of a whole range of other elements, such as the consideration of consumer needs, company goals, competition activities. Accordingly, the main elements included in price decision-making are: costs, customers, company, and competition. Marketing managers must always bear in mind the fact that external economic factors such as inflation, the economic cycle (if the economy of a country is in recession), changes in local conditions due to the emergence of new retail outlets whose phenomenon can serve larger companies but can endanger small national shops (which has happened in Serbia in the last ten years when a range of small boutiques and fashion shops have been closed and large shopping centers have been opened to sell certain brands, but also the counterfeit items).

\section{Cost-based Pricing}

Changes in the price of the final fashion product that are due to the cost price change are at the expense of profit, i.e. the profit rate decreases.

Cost-based price modification is possible under the influence of the following factors: the price recommended by manufacturers, the indicators of trade prices, the price of competing manufacturers, and the desired gross profit margin.

In this regard, the following combinations are possible:

- standard increase - when a percentage increase is added to a determined amount of actual costs. In this case, factors such as the costs of promotional activities and total marketing costs, competitor prices and marginal costs, are not considered. This system is often applied, and the point is that the price paid by the consumer doubles. As a result, manufacturer or a wholesaler often recommends a retail price. 
- target pricing - the expected sales volume is taken into account when determining the price.

- demand-based pricing - the higher the demand, the lower the price, and vice versa.

- stabilization cost - in periods of high inflation and interest rates costs of production, distribution and retail can grow rapidly. The prices of some items will be determined at the beginning of the season. Changes due to a change in the cost price are at the expense of profit, i.e. the profit rate decreases.

\section{Market-based Pricing}

Market-based pricing does not imply only the costs as a basis, but also the achievement of certain company goals. Standard pricing methods are: market screening - when high prices are determined while the product is new and attractive, in order to maximize profit, and market penetration - a method that uses lower product prices in order to attract as many customers as possible and thus maximize profit. Given the specificity of the fashion industry, the marketing sector always uses the first method, primarily due to a short period between two seasons and the launch of a new collection.

Methods of market-based pricing, when it comes to sales directly intended for the consumer, are: psychological pricing - prestige (high price) and value (brand value or brand name, also called "value clothing"), determining the price range - an assortment of different styles within approximate prices (the consumer's habit to buy at a certain price, focusing on the price tag), and competition-based pricing - several retail chains offer the same or similar items, so the manufacturer is not focused on the selection of a label, but on the value it receives for the same amount.

\section{Promoting a Fashion Product}

Promotion is a permanent communication process led by the fashion house with consumers, but also with the complete environment. Today, Internet services, in conjunction with communication media, provide the broadest enhancement of information and communication resources, enabling freelance writing on the subject for websites, blogs, magazines and other reference sources (Radović-Marković, 2018). 
The promotional mix in the fashion industry consists of: advertising, personal selling, sales promotion and public relations (Završnik \& Mumel, 2007), but the effectiveness of marketing communications depends largely on a successful combination of personal selling and public relations elements. The resources available to a PR manager are: organizing interviews, press releases, photographs, events (such as press conferences), fashion shows, commercial exhibitions. Fashion companies can significantly differ in the way they organize their public relations, but they all have the same goal, i.e. establishing good relationships with customers in terms of understanding, and maintaining such relationships with the goal of further improvement. These relationships are measurable through the final sales effect.

\section{Fashion Magazines}

When it comes to fashion magazines, Serbia has followed the world trends more or less successfully. The first women's magazine appeared in Serbia in 1879, and in the beginning of the 20th century ten magazines were in circulation and had distinctive names based on gender (Woman, Housekeeper, Serbian Woman, Sister by Blood, Women's World). After the war, the magazines such as Taste, Practical Woman, Bazaar and Nada, emerged. Today, licensed issues of world magazines, such as Elle, Grazia, Harpers Bazaar, are mostly published. Many of them put an emphasis on electronic editions or web portals, while Beauty and Health, Lisa, Story, Joy, Ana, Men's Health, Best shop, Hello, are most often seen at press kiosks.

Bazaar, a fashion magazine with a half-century tradition, founded in 1964, played an important role in the creation of a fashion establishment in post-war Yugoslavia. As early as in 1967, it launched a critically intricate series of articles on national fashion items such as fashion details, lingerie, makeup and confectionery. The main remarks addressed to the Yugoslav fashion industry related to poor design and quality of clothing. In accordance with the social requirements for the design industry, as early as next year Bazar launched a campaign called "Still Bazaar", whose main goal was defined as a collaboration between the fashion magazine and the manufacturer, aimed at offering beautiful and acceptable models to the market. This campaign promoted Aleksandar Joksimović, the first fashion Bazaar editor, into the main propagator of a new design (Velimirović, 2008). 


\section{Fashion Blogs}

In the last few years there has been a massive appearance and popularization of fashion blogs, first in the world, and then in the national blogosphere, where many interesting fashion and lifestyle blogs emerged. After just a few years dozens of them have emerged and are now already diversified in several directions. There are bloggers who represent their own personal style and thus present the latest fashion trends. The first to impose themselves in this group were Frashion by Marina, Fashion and Style by Vanja Milicevic, Brana's Divine World, launched by Brana Antonović. The success of the Zorannah blog attracted the greatest attention and caused contradictory opinions and discussions. It was launched by Zorana Jovanović (having over 903,000 followers on Instagram). Today, she has her online shop and an actual Pop-Up Shop in Delta City shopping mall and earns from blog posts between EUR 1,000 and 5,000 a month (depending on the number of clients in a particular month). The price for a link in the post reaches EUR 500 and the price for a completely branded post (e.g. to take pictures completely dressed in one brand while mentioning only one brand in the post) amounts to EUR 1,000 (Slijepčević, 2016). A large number of followers on Instagram is also recorded by the following bloggers from Serbia: Tamara Kalinić (over 710 thousand), Marija Žeželj (over 653 thousand), Jana Dačović (over 630 thousand), Mima (over 238 thousand), Anastasija Đurić (over 157 thousand), Nataša Vukobratović (over 133 thousand), who write about events in the fashion world, current trends, fashion editorials and campaigns of famous brands, with some exclusive insider information, and about travel and lifestyle - interior, design, jewelry. Finally, there are fashion web portals in our region, such as Wannabemagazine.com and Style.rs, which also achieved enormous success.

The emergence of social networks enables the development and application of novelties in advertising and an interactive communication between bloggers (influential persons) and their followers (consumers). According to research by Harmon-Kizer (2017), celebrities in their capacity as consumers and promoters can improve the effectiveness of advertising.

Until a survey had been conducted by BeeBlog Network in 2015 (according to: Start IT, 2016), we did not know much about the blogosphere in our region. BeeBlog surveyed 701 bloggers from 6 countries: Serbia, Croatia, Slovenia, Bosnia and Herzegovina, Macedonia and Montenegro, through a questionnaire comprising 70 questions divided into 10 areas. In Serbia, there are more women (57\%) than men among bloggers. Among the 
respondents, there are bloggers of all generations, from minors to $60+$ yearolds, and most of them are in age group 31 to 40. More than three quarters of them completed the university studies or some vocational or specialist studies. Bloggers mostly live in major cities, and the majority of them come from Belgrade (49\%), Novi Sad (16\%) and Niš (5\%). The potential of a blog as a tool for self-employment and the possibility to professionalize the blog and create professional full-time employment or additional source of income is also evident in the blogosphere in the region. More than half of the bloggers write simply as a hobby. Female respondents blog more often as a hobby, while mail respondents indicate that hobby is their job. Every fifth blogger makes money from a blog. While in the United States of America over $54 \%$ of bloggers supplement home budget from blog jobs, and as much as $18 \%$ of them write blogs as part of their full-time jobs, the BeeBlogNetwork survey sample shows that every fifth blogger in our region has had the opportunity to supplement his budget from blog job (21\%). When it comes to revenues, these are usually symbolic budget additions, between EUR 50 and 100. Bloggers with more than four years of working experience in blogging have the opportunity to generate income amounting between EUR 300 and 500 per a post, and only three bloggers in the total sample generate said amount per a post continuously, as monthly income. Most bloggers indicate that their blog contains up to 500 words (46\%), while $32 \%$ of bloggers write posts comprising 500 to 1500 words. Instagram, Facebook and YouTube are the most popular social media among bloggers.

At the DIABLOG conference, the results were presented of the second research on the situation at the Croatian blogging scene, conducted in October 2017 by Dialogue Communications agency (according to: Marketing mreža, 2017). The research included 171 active bloggers. Most respondents were women (90.6\%) aged between 25 and 35, holding diplomas of higher education (42.7\%). Although they still consider blogging a hobby, more bloggers make money from their blogs than in 2016, and they are present mostly on Facebook and Instagram, whose use is on the rise. Most of them make between HRK 3,500 and 5,500 a month. Respondents indicate that they deal with blog writing between three and five years (36.6\%) and publish two to three blog posts a month (42.1\%). Most bloggers cooperate with brand names (77.8\%), and cooperation involves cash compensation or noncash compensation in products/services. They highlight "live" reports, video and Instagram story as trends. 


\section{Conclusion}

This paper presents the elements of the creative process in the emergence and diffusion of a fashion creation, the life cycles of clothing, style, fashion and fashion hit, the pricing methods, as well as the tools for promoting the fashion product with focus on personal selling, public relations and fashion magazines and blogs, while listing examples from fashion practice and presenting the results of secondary research on bloggers in Serbia and in the region where women dominate in their capacity as actors.

The development and liberalization of the modern fashion market have led to the development of a growing importance of certain elements throughout the process, from manufacturing to selling fashion items. In parallel with technological development the market has developed, consumers have become increasingly demanding and more sensitive, both in terms of quality and design of fashion products, as well as in terms of speed of service delivery, sellers attitude towards them, readiness to make additional efforts in the organization and arranging of facilities intended for sale. "Art forms in fashion reappear in modified forms to represent new contexts, new resources and new times. The innovative transformation represents easiness of thoughts, continuity through integration of old and new, and/or departure from old to create new entities" (Chowdhary, 2015).

Successful fashion companies are those who manage to find an optimal relationship between key factors and to continuously improve and modernize their business models by constantly following the market, technology, trends and consumers. One of the trends refers to new forms of promotion on the Internet, through social media, where great opportunities for entrepreneurship and self-employment are mostly seized by women who run their own blogs, thereby contributing to fashion diffusion.

Serbia has a huge potential for the development of women entrepreneurship (Jovanović \& Lazić, 2018), and has the capacity to expand the activities of the textile and leather processing industry. The authors of this paper emphasize the importance of fashion marketing which creates space to apply the said in practical and scientific terms in Serbia, and they hope that this paper will encourage others to think and conduct further empirical research on this subject because "it is no longer fashionable to be fashionable" (Yves Saint Laurent, according to: Odak, 2003). 


\section{References}

[1] Bohdanowicz, J., Clamp, L. 1994. "Fashion Marketing." Routledge and Kegan Paul.

[2] Chowdhary, Usha. 2015. "Shifting Fashion Paradigm: From Status Quo to Mostly Business." American International Journal of Social Science, 4(6): 40-45.

http://www.aijssnet.com/journals/Vol_4_No_6_December_2015/5.pdf.

[3] Drvar, Zlatko. 1997. "Moda i dizajn u marketingu i proizvodnji tekstila i odjeće." Tekstil, 46(1): 2-10.

[4] Fallers, Lloyd A. 1954. "A Note on Trickle Effect." The Public Opinion Quarterly, 18(3): 314-321. https://www.jstor.org/stable/2745991.

[5] Field, George A. 1970. "The Status Float Phenomenon: The Upward Diffusion of Innovations." Business Horizons, 13: 45-52. https://doi.org/10.1016/0007-6813(70)90157-6.

[6] Gašović, Milan. 1998. "Modni marketing." Belgrade: Institute of Economic Sciences

[7] Grilec Kaurić, Alica. 2009. "Marketing mode u industriji tekstila i odjeće." Tržište, 21(2): 219-234. https://hrcak.srce.hr/53124.

[8] Gronow, Jukka. 2000. "Sociologija ukusa." Zagreb: Jesenski i Turk.

[9] Harmon-Kizer, Tracy R. 2017. "The Effects of Schema Congruity on Consumer Response to Celebrity Advertising." Journal of Marketing Communications, 23(2):

162-175.

https://www.tandfonline.com/doi/full/10.1080/13527266.2014.975831

[10] Jovanović, Olivera \& Milena Lazić. 2018. "Women Entrepreneurship in Serbia - Potentials and Constraints." Journal of Women's Entrepreneurship $\begin{array}{lll}\text { and } \quad \text { Education, } & \text { 60-72. }\end{array}$ https://www.library.ien.bg.ac.rs/index.php/jwee/article/view/650/533

[11] Kotler, Philip, Gary Armstrong, John Saunders \& Veronica Wong. 1999. "Principles of Marketing" (Second European Edition). Prentice-Hall Europe.

[12] Kotler, Philip, Kevin Lane Keller. 2006. "Marketing Management" (Twelfth edition). New Jersey, USA: Pearson, Prentice Hall, Upper Saddle River.

[13] Marketing mreža. 2017. Most Croatian bloggers earn between HRK 3,500 and 5,500 a month! https://marketingmreza.rs/vecina-hrvatskih-blogeramesecno-zaradjuje-izmedju-3-500-5-500-kuna/ (accessed June 26, 2018).

[14] Milosavljević, M. 2001. "Marketing." Belgrade: Savremena administracija.

[15] Odak, Iva. 2003. "Moda u društvu: suvremena sociologijska tumačenja." Revija za sociologiju, 34(1-2): 97-107. https://hrcak.srce.hr/14488.

[16] Statistical Office of the Republic of Serbia - SORS. 2018. Statistical Yearbook of the Republic of Serbia 2018. 
http://publikacije.stat.gov.rs/G2018/Pdf/G20182051.pdf (accessed November 28, 2018).

[17] Radović-Marković, Mirjana. 2018. "Female Entrepreneurship Opportunity: Home-Based Genealogy Business." Journal of Women's Entrepreneurship and Education, 3-4: 20-33. https://www.library.ien.bg.ac.rs/index.php/jwee/article/view/638/531

[18] Rogers, Everett M. 1983. "Diffusion of Innovations" (3rd ed.), p. 42. USA, New York: The Free https://teddykw2.files.wordpress.com/2012/07/everett-m-rogers-diffusionof-innovations.pdf.

[19] Rogers, Everett M. 1976. "New Product Adoption and Diffusion." Journal of Consumer Research, 2(4): 290-301. https://www.jstor.org/stable/2488658.

[20] Slijepčević, Milica. 2016. "Modni marketing." Belgrade: HERAedu

[21] Start IT. 2016. Regional bloggers are predominantly holders of a higher education diplomas, every fifth blogger makes money from writing. https://startit.rs/blogeri-srbija-region-statistika/ (accessed June 26, 2018).

[22] Velimirović, Danijela. 2008. "Aleksandar Joksimović - moda i identitet." Belgrade: Utopija.

[23] Završnik, Bruno, Damijan Mumel. 2007. "The Use of Marketing Communications in the Clothing Industry in Slovenia." FIBRES \& TEXTILES in Eastern Europe, 15(1): 11-15. http://www.fibtex.lodz.pl/article1070.html.

\section{Bloggers internet sources:}

[24] Anastasija. https://www.instagram.com/anastasija/

[25] Brana’s Divine World. https://branasdivineworld.com/

[26] Frashion by Marina. http://frashionbymarina.blogspot.com/

[27] Fashion and Style by Vanja Milicevic. http://fashionandstylev.blogspot.com/

[28] Jana Dačović. https://www.instagram.com/janadacovic/

[29] Marija Žeželj. https://www.instagram.com/marijazezelj/

[30] Mima. https://www.instagram.com/miimma_mima/

[31] Nataša Vukobratović. https://www.instagram.com/natasablair/

[32] Tamara Kalinić. https://www.instagram.com/tamara/

[33] Zorannah. http://www.zorannah.com/, https://www.instagram.com/zorannah/

Article history: Received: 14 February, 2019

Accepted: 31 March, 2019 